\title{
MODEL IDEAL PARTISIPASI MASYARAKAT DALAM PEMBENTUKAN PERATURAN DAERAH
}

\author{
Iza Rumesten R.S. \\ Fakultas Hukum Universitas Sriwijaya \\ E-mail: rumesten_iza@yahoo.com
}

\begin{abstract}
There are some negative phenomena in this autonomy era that changing of new local regulation that has just legalized and not effectively implemented with the new regulation that not relevant with the society need. This regulation has been changed because its contradictive with the higher regulations. It phenomena happen because of less participation of the society in making the local regulation, started from the making process to the evaluation process.
\end{abstract}

Keywords: ideal model, public participation, local regulation

\begin{abstract}
Abstrak
Di era otonomi masih berkembang berbagai fenomena negatif diantaranya adalah adanya perda yang baru saja disahkan dan belum berlaku secara efektif sudah diganti dengan perda yang baru, perda yang kurang relevan dengan kebutuhan masyarakat. Perda yang diterbitkan pemerintah daerah dicabut pemerintah pusat karena bertentangan dengan peraturan yang lebih tinggi. Hal tersebut terjadi karena disebabkan banyak hal salah satunya adalah karena kurangnya partisipasi aktif masyarakat dalam pembuatan peraturan daerah mulai dari proses pembuatan rancangan peraturan daerah sampai dengan tahap evaluasi.
\end{abstract}

Kata Kunci: model ideal, partisipasi masyarakat, peraturan daerah

\section{Pendahuluan}

Hukum dalam pembangunan semakin berperan sebagai alat/sarana menyusun tata kehidupan. Hasim Purba mengatakan bahwa pembangunan hukum di Indonesia diharapkan dapat memantapkan dan mengamankan pelaksanaan pembangunan, menciptakan kondisi yang membuat anggota masyarakat dapat menikmati iklim kepastian dan ketertiban hukum. ${ }^{1}$ J utta Limbach mengatakan ada tiga ciri utama yang menandai prinsip supremasi konstitusi. Pertama, pembedaan antara norma hukum konstitusi dan norma hukum lainnya; ke-dua, keterikatan penguasa terhadap Undang-Undang Dasar; dan ketiga, adanya satu lembaga yang memiliki kewenangan untuk menguji konstitusionalitas undang-undang dan tindakan hukum

Hasim Purba, "Sinkronisasi dan Harmonisasi Sistem Hukum Nasional Bidang Pertambangan, Kehutanan, Pertanahan dan Lingkungan Hidup", Jurnal Hukum Equality, Vol. 13 No. 2 Agustus 2008, FH USU Medan, hlm. 171.
Pemerintah. ${ }^{2}$ Dalam hal ini, pelibatan pe-ran serta masyarakat secara aktif masuk dalam poin kedua karena hal ini termaktub dalam UUD 1945, sehingga pemerintah berkewajiban untuk melibatkan masyarakat dalam pembuatan peraturan daerah secara lisan atau tertulis. ${ }^{3}$ Alexander Abdullah mengatakan partisipasi publik harus diberikan tidak saja dalam arti prosedural, tetapi juga harus dilembagakan sebagai hak-hak rak-yat yang dijamin secara normatif. ${ }^{4}$

Maria Farida Indrati mengatakan bahwa masyarakat berhak memberikan masukan dalam Peraturan daerah untuk setiap propinsi, kabupaten dan kota secara berbeda-beda. Hal ini di-

2 J utta Limbach, "The Concept of the Supremacy of the Constitution", The Modern Law Review, Vol. 64 No. 1 J anuari 2001, hlm. 3

3 Maria Farida Indrati, "Proses Pembentukan Peraturan Perundang-undangan Pasca Amandemen UUD 1945", Majalah Hukum Nasional Jakarta, No. 1 Tahun 2005, hlm. 98

$4 \quad$ Alexander Abdullah, "Desentralisasi dan Undang-undang Otonomi Daerah di Era Reformasi, J urnal Hukum Vol. 3 No. 1 J anuari 2010, Ull Yogyakarta, hlm. 25 
sebabkan karena adanya perbedaan sumber daya yang tidak dapat disamakan dalam hal pengelolaannya, terutama berkaitan dengan materi. Hal ini senada dengan pendapat yang di sampaikan oleh I Made Dedy Priyanto yang mengatakan bahwa penyelenggaraan pemerintahan daerah haruslah disesuaikan dengan daerah masing-masing melalui suatu kebijakan aturan yang disesuaikan dengan keadaan daerah setempat, aturan inilah yang disebut dengan perda. ${ }^{5}$ Peraturan daerah pada hakikatnya adalah merupakan bagian yang tak tak terpisahkan dari kesatuan sistem hukum nasional. ${ }^{6}$ Peraturan daerah yang dibuat harus sinkron dan harmonis dengan peraturan perundang-undangan lainnya.

Penerapan sistem desentralisasi dalam era otonomi memberikan dampak positif dan negatif kepada masyarakat. Salah satu dampak positifnya adalah meningkatnya kesadaran politik masyarakat dalam setiap rangkaian pesta demokrasi dan dalam proses pembuatan kebijakan publik. Didik Sukriono mengatakan otonomi dan demokrasi merupakan satu kesatuan semangat sebagai bentuk pemerintahan yang menempatkan rakyat sebagai penentu yang utama dalam negara, ${ }^{7}$ bahkan Suharizal mengatakan demokrasi di daerah merupakan prasyarat bagi munculnya demokrasi di tingkat nasional. ${ }^{8} \mathrm{M}$. Syawalludin mengatakan pemerintah harus memberikan ruang dan peran yang besar bagi keterlibatan politik masyarakat secara aktif dalam penyelenggaraan negara, ${ }^{9}$ bahkan Hodio Potimbang mengatakan masyarakat berhak bahkan wajib berpolitik untuk menentukan haluan

5 I Made Dedy Priyanto, "Kewenangan Gubernur dalam Pembatalan Perda Kabupaten Tabanan", Jurnal Advokasi Vol. 1 No. 1 Tahun 2011, FH Univ. Mahasaraswati Denpasar, hlm. 14.

6 Didik Sukriono, "Pembentukan dan Pengawasan Produk Hukum Daerah", Jurnal Hukum Adil Vol. 2 No. 2 Agustus 2011, Fakultas Hukum Yarsi J akarta, hlm. 168

7 Didik Sukriono, "Membela Desa dengan Desentralisasi dan Melawan desa dengan Demokratisasi", Jurnal Yustika Vol. 12 No. 2 Desember 2009, Fakultas Hukum Universitas Surabaya, hlm. 149.

8 Suharizal, "Penguatan demokrasi Lokal Melalui Penghapusan J abatan Wakil Kepala Daerah", Jurnal Konstitusi, Vol. 7 No. 5 Oktober 2010, hlm. 95

9 M. Syawalluddin, "Pilkada Langsung dan Penegakan Konstitusionalisme; Bingkai Upaya Mewujudkan KemasIahatan Umat", Jurnal Universalisme Islam Mimbar Akademik Vol. 2 No. 1 J uni 2006, Direktorat Pembinaan Badan Peradilan Agama Islam J akarta, hlm. 127 negara membuat Undang-undang dan mengawasi pelaksanaan kekuasaan negara. ${ }^{10}$ Dampak negatifnya adalah sebagai berikut. Pertama, banyak peraturan perundangan yang baru saja disahkan bahkan belum berlaku secara efektif sudah diganti dengan peraturan perundangan yang baru, karena tidak dapat berlaku efektif dalam kehidupan masyarakat dan menimbulkan masalah sosial baru; kedua, banyak Undangundang yang kurang relevan dengan kebutuhan atau permasalahan dalam masyarakat, misalnya UU Pemekaran Wilayah dan Undang-undang tentang Pajak Pertambahan Nilai; ketiga, banyaknya peraturan daerah yang diterbitkan oleh pemerintah daerah yang dicabut oleh pemerintah pusat (Mendagri) karena bertentangan dengan peraturan yang lebih tinggi. Oka Mahendra mengatakan bahwa dalam hierarkhi peraturan perundang-undangan peraturan daerah menempati jenjang paling rendah sehingga tidak boleh bertentangan dengan peraturan yang lebih tinggi dan kepentingan umum, ${ }^{11}$ terutama peraturan daerah yang berkaitan langsung dengan bidang ekonomi, bahkan banyak peraturan daerah yang justru menimbulkan dan menyebabkan kerugian bagi negara.

Mahfud MD mengatakan bahwa politik seringkali mengintervensi pembuatan dan pelaksanaan hukum, sehingga tidak selalu menjamin kepastian hukum, penegakan hak-hak masyarakat atau penjamin keadilan. Konfigurasi politik demokratis akan menciptakan hukum responsif, sedangkan konfigurasi politik otoriter akan menciptakan produk hukum konservatif. Masih berkaitan dengan hal ini, Taufiqurrahman yang mengutip pendapat Bentham mengatakan manusia tunduk kepada hukum adalah karena dengan tunduk kepada hukum mereka merasa membutuhkan atau bermanfaat (utility) ${ }^{12}$. Be-

10 Hodio Potimbang, "Faktor-faktor yang Melahirkan Peradilan Massa ditinjau dari Aspek Hukum Pidana", Majalah Varia Peradilan No. 302 J anuari 2011, hlm. 55

11 Oka Mahendra, "Mekanisme Penyusunan Dan Pengolahan Program Legislasi Daerah", Jurnal Legislasi Indonesia Vol. 3 No. 1 Maret 2006, Ditjen Peraturan Perundangan-undangan J akarta, hlm. 22

12 Taufiqurrahman, "Konvergensi Paradigma Dalam Perubahan Karakter Pilihan Hukum Di Bidang Kontrak J ual Beli Barang Internasional", J urnal Repertorium, Vol. 1 No. 1 Tahun 2010, hlm 115. 
gitupun masyarakat, mereka akan dengan sadar tunduk dan melaksanakan hukum apabila merasakan manfaat dari hukum tersebut.

Menurut W. Riawan Tjandra dan Kresno Budi Sudarsono, pasca reformasi terjadi pergeseran dari rechtsstaat menjadi political state, padahal tujuan negara hukum (goal of state) adalah supremasi hukum. Political state ibarat bis malam, tidak berdiri di atas "rel" hukum yang berlaku. Baik buruknya, bersih/kotornya Pemerintah Daerah sangat tergantung pada kualitas pengaturan hukumnya. Analog dengan hal itu, diperlukan eksekutif, legislatif dan produk hukumnya yang berkualitas secara hukum. Produk hukum tersebut mempengaruhi kualitas negara hukum. ${ }^{13}$ Dalam pembuatan produk hukum J angan berprinsip bahwa pasar akan terus berjalan sesuai koridor, tak akan pernah memikirkan agenda-agenda sosial, hanya berkutat pada urusan bagaimana menghasilkan keuntungan dengan maksimal tanpa tahu menahu dampaknya bagi masyarakat. ${ }^{14}$ Karena produk hukum yang dibuat dengan berprinsip seperti itu tidak akan dapat berlaku secara efektif dalam masyarakat. Produk hukum yang baik juga harus harmonis dan sinkron dengan peraturan perundang-undangan yang diatasnya, Bayu Dwi Anggono mengatakan harmonisasi tidak hanya menyangkut hal-hal yang bersifat yang dimaksudkan untuk menghindari pengaturan yang tumpang tindih atau saling bertentangan tapi lebih dari itu agar peraturan perundang-undngan yang dilahirkan dan kemudahan hukum positif dapat menjalankan fungsinya dengan baik dalam masyarakat. ${ }^{15}$ Masih berkaitan dengan hal ini Bagir Manan mengatakan pembentukan hukum yang baik harus memiliki berbagai syarat pembentukan yang baik pula, seperti asas, asas tujuan, asas kewenangan, asas

13 W. Riawan Tjandra dan Kresno Budi Sudarsono, 2009, Legislative Drafting: Teori dan Teknik Pembuatan Peraturan Daerah, Yogyakarta:Universitas Atmaj aya, hlm. 85.

14 Setiawan, Bonnie, amalia (ed), "Institute For Global J ustice", J urnal Keadilan Global J akarta, No. 01 Tahun 2003, hlm. 16.

15 Bayu Dwi Anggono, “Harmonisasi Peraturan Perundangundangan di bidang penanggu-langan Bencana", J urnal Mimbar Hukum Vol. 22 No. 2 J uni 2010, FH UGM, hlm. 385-386. keperluan mengadakan peraturan, asas bahwa peraturan tersebut dapat dilaksanakan dan lain. ${ }^{16}$

Sejak otonomi daerah diterapkan berdasarkan UU No. 22 Tahun 1999 yang kemudian dicabut dan diganti dengan UU No. 32 Tahun 2004, sudah ribuan Peraturan Daerah yang di buat oleh Pemerintah Daerah, baik pada level propinsi maupun kabupetan/ kota. Data yang di peroleh dari Departemen Keuangan, sampai Desember 2006 terdapat 9.617 Peraturan Daerah yang terkait dengan perizinan, pajak dan retribusi di daerah. Data yang diperoleh dari Departemen Dalam Negeri menunjukkan bahwa sejak tahun 2002 sampai tahun 2007, Peraturan Daerah yang dibatalkan baru berjumlah 761 Peraturan Daerah. Bahkan Subiharta mengatakan bahkan ada perda yang tidak sah tetapi daerah masih tetap memberlakukan. ${ }^{17}$ Peraturan Daerah yang dianggap bermasalah itu, dinilai menimbulkan ekonomi biaya tinggi di daerah serta juga membebani masyarakat dan lingkungan. ${ }^{18}$

Hal ini terjadi karena peraturan daerah yang dibuat oleh pemerintah daerah tidak partisipatif artinya belum mampu mengcover aspirasi semua lapisan masyarakat, sehingga ketika akan diberlakukan bertentangan dengan apa yang diinginkan masyarakat. Hal ini tentu saja sangat mengganggu jalannya sistem pemerintahan yang artinya juga mengganggu kestabilan masyarakat di daerah, terutama dari segi kepastian hukumnya. Berangkat dari uraian tersebut, maka tulisan ini akan mengangkat tentang model ideal partisipasi masyarakat dalam proses pembentukan peraturan daerah dan kendala yang timbul dalam upaya melibatkan partisipasi aktif masyarakat dalam pembentukan peraturan daerah.

\section{Pembahasan}

16 Bagir Manan, "Konsistensi Pembangungan Nasional dan Penegakan Hukum", Majalah Varia Peradilan No. 275 Okto-ber 2008, hlm. 10.

17 Subiharta, "Pajak Daerah dan Retribusi Daerah Dalam Perspektif UU No. 28 Tahun 2009", Majalah Varia Peradilan, No. 305 April 2011, hlm. 21.

18 W. Riawan Tjandra dan Kresno Budi Sudarsono, Op.cit, 154-155. 


\section{Bentuk Partisipasi Masyarakat dalam Proses Pembentukan Peraturan Daerah}

Partisipasi masyarakat dalam pembentukan peraturan perundang-undangan dapat diartikan sebagai partisipasi politik, oleh Huntington dan Nelson partisipasi politik diartikan sebagai kegiatan warga negara sipil (pivate citizen) yang bertujuan untuk mempengaruhi pengambilan keputusan oleh pemerintah. ${ }^{19}$ Partisipasi dan pelibatan masyarakat dalam proses rencana pembuatan kebijakan publik, program kebijakan publik, proses pengambilan keputusan publik dan alasan dari pengambilan keputusan publik merupakan salah satu ciri dari penyelenggaraan negara demokratis. ${ }^{20}$ Berkaitan dengan hal ini Bagir Maman mengatakan bahwa kebebasan politik ditandai dengan adanya rasa tentram, karena setiap orang merasa dijamin keamanannya atau kesela-matannya. ${ }^{21}$ Bentuk partisipasi masyarakat dalam pemerintahan, khususnya dalam pembentukan peraturan daerah sangat bervariasi, tergantung pada situasi dan kondisi disuatu tempat dan waktu. Dalam negara demokrasi dengan sistem perwakilan, kekuasaan pembentukan undang-undang atau Peraturan Daerah hanya ada ditangan kelompok orang-orang yang telah dipilih melalui pemilihan umum. Dalam hal ini, setiap wakil itu akan bertarung di parlemen demi kepentingan umum dan bila mereka bertindak sebaliknya, maka kursi yang didudukinya akan hilang dalam pemilihan umum yang akan datang, digantikan oleh orang lain dari partai yang sama ataupun dari partai yang berbeda. Disinilah letak titik kontrol yang utama dari rakyat kepada wakilnya di parlemen. Alat kontrol lain yang dipergunakan masyarakat adalah demonstrasi atau bentuk-

19 Iza Rumesten RS, "Relevansi Partisipasi Masyarakat dalam Perancangan Pembentukan Peraturan Perundangundangan Yang Responsif", J urnal Simbur Cahaya Vol. XVI No. 44 J anuari 2011, Unit Penelitian FH Universitas Sriwij aya Palembang, hlm. 2327.

20 Saut P. Panjaitan, "J aminan Perlindungan Konstitusional Hak Tiap Orang Untuk Memperoleh Informasi dan Berkomunikasi", J urnal Simbur Cahaya, Vol. XV No. 42 Mei 2010, Unit Penelitian FH Universitas Sriwijaya Palembang, hlm. 1957-1958.

21 Lihat dalam Muhammad Aziz, "Pengujian Peraturan Perundang-undangan dalam Sistem Peraturan Perundang-undangan Indonesia", J urnal Konstitusi, Vol. 7 No. 5 Okto-ber 2010, hlm. 122 bentuk pengerahan massa lainnya, atau bisa juga melalui prosedur hukum. Dengan demikian, untuk mencapai tujuan peraturan perundang-undangan tersebut syarat pertama yang harus dipenuhi adalah keterlibatan rakyat/ partisipasi aktif masyarakat dalam suatu proses pembentukan Peraturan Daerah atau kebijakan lainnya mulai dari proses pembentukannya, proses pelaksanaannya di lapangan dan terakhir tahap evaluasi.

Sehubungan dengan partisipasi aktif masyarakat dalam pembentukan Peraturan Daerah, maka perlu juga dikemukakan pandangan M. Riawan Tjandra dan Kresno Budi Sudarsono, yang menegaskan terdapat tiga akses (three accesses) yang perlu disediakan bagi masyarakat dalam penyelenggaraan pemerintahan. Pertama, akses terhadap informasi yang meliputi 2 (dua) tipe yaitu hak akses informasi pasif da hak informasi aktif; kedua, akses partisipasi dalam pengalihan keputusan (public participation in decision making) meliputi hak masyarakat untuk mempengaruhi pengambilan keputusan, partisipasi dalam penetapan kebijakan, rencana dan program pembangunan dan partisipasi dalarn pernbentukan peraturan perundangundangan; dan ketiga, akses terhadap keadilan (access to justice) dengan menyediakan mekanisme bagi masyarakat untuk menegakkan hukum lingkungan secara langsung (the justice pillar also provides a mechanism for public to enforce environmental law directly). Sifat dasar dan peran serta adalah keterbukaan (openness) dan transparansi (transparency). ${ }^{22}$

Lebih lanjut, M. Riawan Tjandra dan Kresno Budi Sudarsono menjelaskan bahwa penguatan tri akses tersebut diyakini dapat mendorong terjadinya perubahan orientasi sikap dan perilaku birokrasi yang semula menjadi service provider menjadi enabler/fasilitator. Perwujudan tri akses tersebut dapat dilihat dalam bebrapa bentuk. Pertama, turut memikirkan dan memperjuangkan nasib sendiri; kedua, kesadaran bermasyarakat dan bernegara. Tidak menyerahkan penentuan nasibnya kepada

22 W. Riawan Tjandra dan Kresno Budi Sudarsono, op.cit, hlm. 43-44. 
orang lain; ketiga, merespons dan bersikap kritis; keempat, penguatan posisi tawar; dan kelima, sumber dan dasar motivasi serta inspirasi yg menjadi kekuatan pelaksanaan tugas dan kewajiban pemerintah. ${ }^{23}$

Sehubungan dengan penjelasan M. Riawan Tjandra dan Kresno Budi Sudarsono, Muhammad Syaifuddin mengatakan:

"Dapat dipahami bahwa prinsip keterbukaan adalah elemen penting dalam penyelenggaraan pemerintahan di kabupaten/ kota, yang berorientasi pada konsep negara kesejahteraan yang bertumpu pada kekuatan masyarakat sipil, dengan bercirikan birokrasi yang efisien, efektif, impersonal, impartial, objektif, rasional dan berorientasi pada kepentingan publik. Prinsip keterbukaan membawa konsekuensi adanya kewajiban bagi Pemerintah Kabupaten/Kota untuk secara proaktif memberikan informasi kepada masyarakat, serta menjelaskan kepada masyarakat tentang ber-bagai hal yang mereka butuhkan. Pelaksanaan prinsip keterbukaan membawa konsekuensi perlunya pelaksanaan prinsip partisipasi masyarakat dalam pembentukan Peraturan Daerah. ${ }^{24}$

Habermas ${ }^{25}$ menyatakan, bahwa titik tolak yang dapat menjadi acuan untuk menata ulang proses pelibatan partisipasi aktif masyarakat tersebut adalah memperluas perdebatan politis dalam parlemen ke masyarakat sipil. Bukan hanya aparat negara dan wakil rakyat, melainkan juga seluruh warga negara berpartisipasi dalam wacana politis untuk mengambil keputusan politik bersama. Melalui radikalisasi konsep negara hukum klasik kedaulatan rakyat bergeser dari proses pengambilan keputusan di parlemen keproses partisipasi dalam ruang publik. Kedaulatan rakyat bukanlah substansi yang membeku dalam perkumpulan para wakil rakyat, melainkan juga terdapat diberbagai forum warga negara, orgnisasi, non pemerintah, gerakan sosial atau singkatnya di mana pun dis-

\footnotetext{
23 Loc.cit

24 Muhammad Syaifuddin, Mada Apriandi Zuhir dan Analisa Yahanan, 2009, Demokratisasi Produk Hukum Ekonomi daerah (pembentukan peraturan daerah demokratis di bidang ekonomi di Kabupaten/Kota, Malang:Tunggal Mandiri Publishing, hlm 263.

25 Lihat dalam Hamzah Halim, op. cit, hlm 123.
}

kursus tentang kepentingan bersama warga negara dilancarkan.

Senada dengan hal ini, Bambang Sugiono dan Ahmad Husni M.D menjelaskan bahwa pelaksanaan prinsip peran serta masyarakat bertujuan untuk: pertama, melahirkan prinsip kecermatan dan kehatihatian dari pejabat publik dalam membuat kebijaksanaan publik; dan kedua, membawa konsekuensi munculnya suatu kontrol sosial yang konstruktif dan kesiapan sosial masyarakat terhadap setiap bentuk dampak akibat suatu kegiatan pembangunan. ${ }^{26}$

Sistem demokrasi yang melibatkan partisipasi aktif masyarakat bertujuan untuk meningkatkan kemampuan rakyat yang rendah dari segi ekonomi, politik, dan sosial. Konsep partisipasi masyarakat mengalami pemaknaan yang berbeda-beda sehingga perlu diperjelas tentang proses yang mana yang dapat disebut partisipasi dan yang bukan, sehingga terjadi kesamaan cara pandang dalam menilai sebuah proses partisipasi di masa lalu, sekarang, dan yang akan datang.

Lebih lanjut Rival G. Ahmad yang mengacu kepada pendapat Arenstein, menyusun model yang dapat membantu untuk menilai tingkat partisipasi dalam suatu proses pembentukan kebijakan atau peraturan secara umum Perundang-undangan/Peraturan Daerah. Secara umum ada tiga derajat partisipasi masyarakat. Pertama, tidak partisipatif (non participation); kedua, derajat semu (degrees of tokenism); dan ketiga, kekuatan masyarakat (degrees of citizen power $)^{27}$

Lebih lanjut dikatakannya "dasar penentuan derajat, bukan pada seberapa jauh masyarakat telah terlibat dalam proses pembentukan kebijakan atau program dilaksanakan oleh negara tetapi seberapa jauh masyarakat dapat menentukan hasil akhir atau dampak dari kebijakan atau program tersebut. Derajat terbawah terdiri dari dua tingkat partisipasi, yaitu manipulasi (manipulation) dan terapi (thera-

26 W. Riawan Tjandra dan Kresno Budi Sudarsono op. cit. hlm. 46.

27 Rival G. Ahmad dkk, "Dan Parlemen ke Ruang Publik: Menggagas Penyusunan Kebijakan Partisipatif" Jurnal Hukum J entera Vol. I No. 2 Tahun 2003, PSHK J akarta, hlm. 108. 
py). Dalam tingkat ini partisipasi hanya bertujuan untuk menata masyarakat dan mengobati luka yang timbul akibat dari kegagalan sistem dan mekanisme pemerintahan. Tidak ada niatan sedikit pun untuk melibatkan masyarakat dalam menyusun kegiatan atau program pemerintah. Derajat menengah (yang semu) terdiri dari tiga tingkat partisipasi, yaitu: pemberitahuan (informing); konsultasi (consultation); dan peredaman (placation). Dalam tahap ini sudah ada perluasan kadar partisipasi, masyarakat sudah bisa mendengar (tingkat pemberitahuan) dan didengar (tingkat konsultasi), namun begitu tahap ini belum menyediakan jaminan yang jelas bagi masyarakat bahwa suara mereka diperhitungkan dalam penentuan hasil sebuah kebijakan publik. Sedangkan pada tahap peredaman memang sudah memungkinkan masyarakat pada umumnya khususnya yang rentan untuk memberikan masukan secara lebih signifikan dalam penentuan hasil kebijakan publik, namun proses pengambilan keputusan masih dipegang penuh oleh pemegang kekuasaan. Derajat tertinggi terdiri dari tiga tingkat partisipasi, yakni kemitraan (partnerships), delegasi kekuasaan (delegated power), dan yang teratas adalah kendali masyarakat (citizen control). Dalam tahap ini partisipasi masyarakat termasuk yang rentan sudah masuk dalam ruang penentuan proses, hasil, dan dampak kebijakan. Masyarakat sudah bisa bernegosiasi dengan penguasa tradisional dalam posisi politik yang sejajar (tingkat kemitraan). Bahkan lebih jauh mampu mengarahkan kebijakan karena ruang pengambilan keputusan telah dikuasai (tingkat delegasi kekuasaan). Sehingga pada tahap akhir partisipasi masyarakat telah sampai pada puncaknya, yaitu ketika masyarakat secara politik maupun administratif sudah mampu mengendalikan proses, pembentukan, pelaksanaan, dan kebijakan tersebut (tingkat kendali masyarakat). ${ }^{28}$

Pembentukan Peraturan Daerah, baik yang berasal dari inisiatif Dewan Perwakilan Rakyat Daerah maupun yang berasal dan inisiatif Pemerintah Daerah dilakukan melalui beberapa tahapan. Adapun tahapan pemben-

28 Hamzah Halim, op.cit, hlm. 124-125. tukan peraturan daerah sama dengan tahapan penyusunan peraturan perundang-perundangan yang lain, meliputi perencanaan, perancangan, pembaha-san, pengesahan, pengundangan, pelaksanaan, dan evaluasi. Ruang partispasi bagi masyarakat harus ada disetiap tahapan tersebut. Dengan demikian, diharapkan akan lahir perda yang partisipatif, masyarakat yang kritis, dan pemerintahan yang responsif terhadap kebutuhan sosial.

Partisipasi masyarakat tidak hanya diperlukan dalam proses penyusunan Peraturan Daerah, namun dalam seluruh tahapan pembentukannya sampai dengan evaluasi. Dalam agenda ROCCIPI-rule, opportunity, communiction, capacity, interest, process, and ideology (peraturan, kesempatan, komunikasi, kemampuan, kepentingan, proses dan nilai/sikap) dinyatakan bahwa dalam penyusunan peraturan yang baik harus memperhatikan tujuh agenda tersebut. Kategori ini dapat memberikan gambaran awal reaksi masyarakat terhadap peraturan yang akan dibentuk. Kategori ROCCIPI mengidentifikasi faktor-faktor yang kerap menimbulkan masalah berkaitan dengan berlakunya suatu peraturan perundang-undangan. Faktor interest dan ideology merupakan faktor yang bersifat subjektif sedangkan rule, opportunity, communication, capacity, dan process merupakan faktor objektif. Agenda ini bermanfaat untuk mempersempit dan mensistematiskan ruang lingkup hipotesis yang muncul dalam benak perancang peraturan tentang penyebab suatu perilaku bermasalah. Dalam agenda ini terdapat faktorfaktor yang memengaruhi peran serta masyarakat dalam pelaksanaan Peraturan Daerah berkaitan materi yang terdapat dalam Peraturan Daerah. Berikut penjelasan dari masing-masing faktor dimaksud.

Pertama, Rule (peraturan). Kepatuhan atau ketidakpatuhan seseorang terhadap suatu peraturan, mungkin terjadi karena banyak peraturan yang tumpang-tindih, tidak jelas, atau multitafsir/ bisa ditafsirkan sesuka hati, bertentangan atau saling tidak mendukung, tidak transparan, tidak accountable dan tidak partisipatif, atau memberikan wewenang yang berlebihan kepada pelaksana peraturan. Dan satu 
hal yang tidak bisa ditawar bahwa peraturan tidak dapat menghilangkan penyebab perilaku bermasalah.

Kedua, Opportunity (kesempatan/peluang). Sebuah peraturan secara tegas melarang perilaku tertentu, namun jika terbuka kesempatan untuk tidak mematuhinya orang dengan mudah melakukan perilaku bermasalah. Pelanggaran terhadap Peraturan Daerah kerap terjadi karena adanya kesempatan dan tidak adanya tindakan tegas dari aparat yang berwenang.

Ketiga, Capacity (kemampuan). Peraturan tidak dapat memerintahkan seseorang untuk melakukan sesuatu yang dia tidak mampu. Peraturan harus dibuat dengan mengetahui kondisi-kondisi masyarakat yang menjadi subjek peraturan. Kemampuan masyarakat dapat dirinci ke dalam kemampuan politik, ekonomi, dan sosial-budaya.

Keempat, Communication (komunikasi). Komunikasi pemerintah daerah dengan rakyat tidak efektif, terutama dalam mengumumkan peraturannya. Media sosialisasi yang digunakan tidak familier dan sulit untuk diakses oleh masyarakat. Hal ini menunjukkan indikasi kesengajaan, supaya masyarakat tidak tahu cacat yang ada di dalam suatu peraturan.

Kelima, Interest (kepentingan). Aspek kepentingan terkait erat dengan manfaat bagi pelaku peran (pembuat peraturan maupun stakeholder/masyarakat yang akan menjadi sasaran pemberlakuan aturan tersebut). Kepentingan ini bisa terdiri dari kepentingan ekonomi, politik, dan sosial-budaya. Keenam, Process (proses). Proses yang dimaksud dalam hal ini adalah proses bagi pelaku untuk memutuskan apakah akan mematuhi atau tidak mematuhi suatu Peraturan Daerah. Proses ini sangat dipengaruhi oleh substansi peraturan yang berdampak positif atau tidak bagi kepentingan masyarakat di mana Peraturan Daerah tersebut diberlakukan. Ketujuh, Ideology (nilai dan sikap). Kategori ideologi ini secara umum dimaknai sebagai sekumpulan nilai yang dianut oleh suatu masyarakat untuk merasa, berpikir, dan bertindak. Termasuk di dalamnya antara lain sikap mental, pandangan tentang dunia, pemahaman keagamaan. Kadang-kadang ideologi ju- ga disamakan dengan budaya yang sangat luas cakupannya. Dalam masyarakat Indonesia yang serba majemuk (beragam) harus dapat diakomodasi oleh pengambil kebijakan agar dapat dengan mudah diterima oleh masyarakat. ${ }^{29}$

Bagaimanapun rumit dan kompleksnya permasalahan yang ditemukan dalam masyarakat, jika dijabarkan berdasarkan kategori ROCCIPI sebagaimana tersebut, kemungkinan besar akan dapat dicegah (preventif) atau dicarikan solusinya, tentunya dengan menyesuaikan dengan substansi (materi) suatu Peraturan Daerah yang hendak dibuat dengan terlebih dahulu melakukan pengkajian terhadap keinginankeinginan atau harapan-harapan dari masyarakat di mana Peraturan Daerah itu kelak hendak diberlakukan. Tentunya pengkajian tersebut disandarkan pada tujuh kategori ROCCIPI tersebut. Meskipun demikian, akan lebih tepat jika dalam setiap proses pembentukan Peraturan Daerah tersebut, masyarakat setempat senantiasa disediakan ruang untuk berpartisipasi dan dijamin adanya informasi mengenai prosedurnya.

Pada dasarnya keikutsertaan masyarakat (partisipasi) dalam proses pembentukan suatu Peraturan Daerah telah diatur dan dijamin oleh Pasal 53 UU No. 10 Tahun 2004. Dengan demikian, maka dapat dikatakan bahwa sesungguhnya telah ada koridor hukum yang jelas melindungi hak atas informasi masyarakat. Ketentuan ini juga berarti dalam pembentukan sebuah Peraturan Daerah harus terdapat prosedur yang memungkinkan masyarakat untuk berperan aktif di dalam proses perancangan tersebut. Berkaitan dengan hal ini, Iza Rumesten mengatakan bahwa naskah akademik merupakan bentuk konkret partisipasi masyarakat dalam rangka pembentukan peraturan perundangundangan (termasuk peraturan daerah yang berbasis riset). ${ }^{30}$

29 Jazim Hamidi, 2006, Revolusi Hukum Indonesia (Makna, kedudukan dan Implikasi Hukum Naskah Proklamasi Indonesia 17 Agustus 1945 dalam Sistem Ketatanegaraan RI), Yogyakarta:Kerjasama Konstitusi Press J akarta dengan Citra Media, hlm. 77.

30 Iza Rumesten RS, "Peningkatan Fungsi Naskah Akademik Dalam Membantu DPRD Menghasilkan Peraturan Daerah Yang Responsif", Jurnal Penelitian Hukum Supremasi Hukum, Vol. 19 No. $1 \mathrm{~J}$ anuari 2010, UNIB, hlm. 51. 
Praktik yang terjadi selama ini dalam proses pembentukan perda peran masyarakat masih bersifat parsial dan simbolis. Beberapa komunikasi massa yang dilakukan hanyalah sebagai pelengkap prosedur adanya basic research yang melandasi perencanaan pembentukan Peraturan Daerah. Itu pun, dilakukan hanya pada tahap perencanaan. Kemudian dalam tahap pembahasan di Dewan Perwakilan Rakyat Daerah, masyarakat yang sudah "terlanjur" mewakilkan kekuasaannya pada wakil rakyat di Dewan Perwakilan Rakyat Daerah tidak lagi mendapatkan hak suara. Sidang paripurna anggota Dewan Perwakilan Rakyat Daerah yang terhormat memang bersifat terbuka, tetapi kebal kritik karena protokol dan tata tertib sidang. Sementara rakyat yang tidak puas, harus cukup puas dengan meneriakkan aspirasi dan kepentingannya dengan cara "itu-itu saja" demo dan unjuk rasa yang tidak pernah efektif. Berkaitan dengan hal tersebut Natabaya mengatakan bahwa DPRD sebagai lembaga politik tidak lepas dari kepentingan politik para anggotanya, menjadi semacam kewajaran dimana saja diseluruh dunia para anggota DPRD menyuarakan aspirasi politik partainya sedangkan aspirasi masyarakat (konstituennya) menjadi nomor $2 .^{31}$

Menurut Sirajuddin, ${ }^{32}$ terdapat sedikitnya 8 (delapan) prinsip mengenai optimalisasi partisipasi masyarakat di dalam proses pembentukan suatu Peraturan Daerah. Pertama, adanya kewaiiban publikasi yang efektif; kedua, adanya kewajiban informasi dan dokumentasi yang sistematis, bebas, dan accessible; ketiga, adanya jaminan prosedur dan forum yang terbuka dan efektif bagi masyarakat untuk terlibat dalam mengawasi proses sejak tahap perencanaan; keempat, adanya prosedur yang menjamin publik bisa mengajukan Rancangan Peraturan Daerah selain anggota Dewan Perwakilan Rak-

31 AS. Natabaya, "Peningkatan Kualitas Peraturan Perundang-undangan (suatu Pendekatan Input dan Output", J urnal Legislasi Indonesia, Vol. 4 No. 2 J uni 2007, hlm. 13-14

32 Sirajudin dkk, 2006, Legislative Drafting; Pelembagaan Metode Partisipasi masyarakat Dalam Penyelenggaraan Otonomi Daerah, Malang: Corruption Watch dan YAPPIKA, hIm. 189. yat Daerah dan pemerintah; kelima, adanya pengaturan yang jelas mengenai dokumen dasar yang wajib tersedia dan accessible seperti naskah akademik dan Rancangan Peraturan Daerah; keenam, adanya jaminan banding bagi publik bila proses pembentukan Peraturan Daerah tidak dilakukan secara partisipatif; ketujuh, ada pengaturan jangka waktu yang memadai untuk seluruh proses penyusunan, pembahasan Rancangan Peraturan Daerah, dan diseminasi Peraturan Daerah yang telah dilaksanakan; dan kedelapan, ada pertanggungjawaban yang jelas dan memadai bagi proses pembentukan Peraturan Daerah yang dengan sengaja menutup peluang masyarakat untuk berpartisipasi. ${ }^{33}$

Sebuah pemerintahan yang baik (good governance) dan demokratis harus menjamin terealisasinya prinsip-prinsip tersebut. Ada beberapa bentuk upaya menjaring partisipasi masyarakat yang dapat dilakukan oleh pembentuk Peraturan Daerah dalam pembentukan Peraturan Daerah. Pertama, melakukan penelitian terpadu sebelum perancangan Peraturan Daerah; kedua, menggelar public hearing materi yang akan diperdakan (hal ini bisa dilakukan di Dewan Perwakilan Rakyat Daerah tetapi juga bisa dilakukan dengan cara turun langsung ke tengah-tengah masyarakat terkait (stakeholder); dan ketiga, memberikan kesempatan kepada warga untuk mengikuti persidangan di kantor DPRD (dengan membuka informasi jadwal sidang pembentukan perda tersebut). ${ }^{34} \mathrm{~J}$ ika kewajiban pemerintah untuk memfasilitasi partisipasi masyarakat telah terpenuhi maka adalah juga menjadi kewajiban masyarakat untuk dapat memanfaatkan fasilitas tersebut secara efektif agar dapat menjadi kekuatatan kontrol dan menjadi pengawas bagi kebijakan yang dikeluarkan pemerintah.

Partisipasi tidak cukup hanya dilakukan oleh sekelompok orang yang duduk di lembaga perwakilan di kabupaten/kota, karena institusi dan orang-orang yang duduk dalam lembaga perwakilan seringkali menggunakan politik atas nama kepentingan rakyat untuk memperjuang-

\footnotetext{
33 Hamzah Halim, op. cit, hlm. 141.

34 Ibid, hlm. 141.
} 
kan kepentingan pribadi atau kelompok mereka sendiri. Partisipasi rakyat secara langsung, menurut Alexander Abe, akan membawa tiga dampak penting. Pertama, terhindar dari peluang terjadinya manipulasi keterlibatan rakyat dan memperjelas apa yang dikehendaki masyarakat; kedua, memberi nilai tambah pada legitimasi rumusan perencanaan, karena semakin banyak jumlah pihak yang terlibat semakin baik; dan ketiga, mening-katkan kesadaran dan keterampilan politik masyarakat. ${ }^{35}$

Pihak-pihak yang terlibat dalam pelaksanaan partisipasi masyarakat yang paling utama adalah masyarakat itu sendiri. Kesadaran berpartisipasi dan dukungan terhadap aktivitas partisipasi melalui pendidikan politik perlu dibangun. Tokoh-tokoh masyarakat dan organisasi lokal baik berupa institusi akademis, media massa, dan lembaga swadaya masyarakat bertanggung jawab terhadap penyelenggaraan pendidikan politik bagi masyarakat. Selain itu, harus ada dukungan dari pemerintah daerah dan Dewan Perwakilan Rakyat Daerah. Mungkin banyak yang beranggapan bahwa partisipasi masyarakat telah cukup (cukup representatif dan legitimatif) terwakili oleh wakil rakyat di Dewan Perwakilan Rakyat Daerah ${ }^{36}$. Namun kini hal itu tidaklah cukup, partisipasi masyarakat lebih dibutuhkan dalam memberi masukan pada saat proses pembuatan peraturan daerah dan memberikan legitimasi terhadap Peraturan Daerah tersebut, karena menurut Rosmala Polani inti dari otonomi daerah adalah demokratisasi dan pemberdayaan. ${ }^{37}$

Masyarakat dapat menyalurkan aspirasi mereka dalam setiap tahap pembentukan Peraturan Daerah, secara aktif maupun pasif. Hal ini diatur dalam konstitusi negara kita. Laica Marzuki mengatakan Konstitusi merupakan naskah legitimasi paham kedaulatan rakyat. Naskah dimaksud merupakan kontrak sosial yang

35 Alexander Abe, 2005, Perencanaan Daerah Partisipatif, Pembaruan, Yogyakarta, hlm. 90-91.

36 Khairul Muluk, 2007, Menggugat Partisipasi Publik Dalam Pemerintah Daerah, Malang: LPD FIA UB dan Bayu Media, hlm. 225.

37 Rosmala Polani, "Pembagian Kewenangan di Wilayah Perairan Pada Era Otonomi Daerah", Jurnal Simbur Cahaya, Vol. XIII No. 35 J anuari 2008, Unit Penelitian FH Universitas Sriwij aya Palembang hlm. 623. mengikat setiap warga dalam membangun paham kedaulatan rakyat. ${ }^{38}$ Partisipasi aktif dalam arti: masyarakat memiliki inisiatif sendiri untuk berperan serta dalam pembentukan Peraturan Daerah. Partisipasi aktif dapat dilakukan dengan cara: mengikuti debat publik, rapat umum, demonstrasi, atau melalui surat terbuka di media massa. Partisipasi pasif, berarti inisiatif partisipasi datang dari luar diri masyarakat. Inisiatif bisa datang dari lembaga legislatif atau eksekutif dengan mengadakan dengar pendapat (hearing), dialog publik, kunjungan kerja, maupun wawancara penelitian dalam rangka perancangan peraturan daerah.

Bentuk-bentuk pelaksanaan partispasi masyarakat sangat tergantung pada situasi dan kondisi masyarakat dan lingkungannya. Tingkat kualitas sumber daya masyarakat, kepedulian lembaga pendidikan atau lembaga swadaya masyarakat dan sikap pemerintah sangat mempengaruhi pola-pola partisipasi yang digunakan oleh masyarakat untuk menyalurkan aspirasinya. Masyarakat berhak menentukan cara yang digunakan untuk berpartisipasi dalam proses penyusunan Peraturan Daerah. Partisipasi dapat dilakukan secara langsung, yaitu dengan ikut serta dalam salah satu atau seluruh proses pembentukan baik dilakukan melalui lembaga eksekutif maupun legislatif. Partisipasi iuga dapat dilakukan secara tidak langsung, yaitu dengan melakukan kegiatan yang kurang lebih dapat mempengaruhi proses pembentukan peraturan daerah. Cara paling konvensional dalam upaya mempengaruhi proses persidangan pembentukan Peraturan Daerah adalah demonstrasi atau unjuk rasa. Undang-Undang Kemerdekaan Menyampaikan Pendapat di Muka Umum No. 9 Tahun 1998 menyatakan bahwa bentuk mengeluarkan pendapat di muka umum adalah unjuk rasa, pawai, mimbar bebas, atau rapat umum. Melalui 4 cara tersebut, masyarakat dapat berpartisipasi meneriakkan keinginan dan sikapnya mengenai materi yang sedang dibahas dalam sidang pembentukan peraturan perundang-undangan. Meskipun cara-cara tersebut kurang

38 Laica Marzuki, "Konstitusi dan Konstitusionalisme" J urnal Konstitusi Vol. 7 No. 4 Agustus 2010, hlm. 2. 
efektif, namun cara ini banyak digunakan karena kurangnya ruang partisipasi secara langsung melalui lembaga pemerintah sangat minim. Diantara model partisipasi yang dapat dilakukan, antara lain: pertama, mengikutsertakan anggota masyarakat yang dianggap sah dan independen dalam team atau kelompok kerja dalam penyusunan peraturan perundangan; kedua, melakukan public hearing melalui seminar, lokakarya atau mengundang pihak-pihak yang berkepentingan dalam rapat-rapat penyusunan peraturan perundang-undangan, musyawarah rencana pembangunan; ketiga, melakukan uji sahih terhadap Peraturan Daerah; keempat, melakukan jajak pendapat, kontak publik melalui media massa; dan kelima, melalui lembaga pemberdayaan masyarakat kelurahan (LPMK) atau membentuk forum warga. ${ }^{39}$

Berkaitan dengan penyusunan Raperda baik di lingkungan Pemerintah Daerah maupun Dewan Perwakilan Rakyat Daerah, secara normatif masayarakat dapat berperan serta secara aktif untuk memberikan masukan perda yang dibentuk. Demikian juga pada saat dilakukan pembahasan bersama antara Dewan Perwakilan Rakyat Daerah dan Pemerintah Daerah, Dewan Perwakilan Rakyat Daerah dapat menyelenggarakan rapat dengar pendapat umum untuk mendapat masukan dari masyarakat umum. Bentuk lain dari partisipasi masyarakat yang dapat di lakukan oleh Dewan Perwakilan Rakyat Daerah dan pemerintah daerah adalah seminar terbatas, Foccus Group Discussion (FGD), Interactional Group Discussion (IGD), dialog publik, sosialisasi berkala dan diskusi ahli. Dalam merumuskan peraturan daerah mengenai PKDRT misalnya bentuk tanggung jawab yang dilakukan pemerintah daerah untuk merumuskan dan merencang perda tersebut pemerintah daerah Sumatera Selatan gencar melakukan sosialisasi dan edukasi tentang KDRT, menyelanggarakan advokasi dan sosialisasi serta menyelenggarakan pendidikan dan pelatihan mengenai sensitifitas gender dan isu-isu mengenai PKDRT (edit

39 Sirajuddin, dkk, op.cit, hlm. 189. penulis), ${ }^{40}$ hanya saja tidak setiap perumusan perda yang melakukan sosialiasi secara gencar dalam perumusan dan pembuatan rancangan peraturan daerah.

\section{Kendala yang Timbul dalam Upaya Melibatkan Partisipasi Masyarakat dalam Pembentukan Peraturan Daerah}

Salah satu tahapan yang penting dilakukan dalam proses penyusunan perda adalah communication, yaitu adanya komunikasi antara pemangku kepentingan dan pengambilan kebi-jakan. Komunikasi ini sangat penting dalam pelaksanaan peraturan daerah. Setidaknya komunikasi yang dapat dilakukan oleh pemerintah adalah sosialisasi. Meskipun bersifat searah, informasi yang didapatkan oleh masyarakat meIalui sosialisasi Peraturan Daerah sedikit banyak dapat memberikan kesempatan masyarakat untuk melaksanakan atau tidak melaksanakan peraturan tersebut sesuai dengan kebutuhannya. Dengan demikian, pelaksanaan Peraturan Daerah yang tidak mencerminkan atau tidak mengakomodasi kepentingan masyarakat mendapat reaksi negatif dari masyarakat. Secara teoretis dalam ilmu hukum dikenal adanya anggapan yang menyatakan bahwa semua orang dianggap tahu hukum, namun teori fiksi ini tidak dapat diberlakukan begitu saja, karena masalah komunikasi sering kali muncul karena selama ini pemerintah (pemerintah daerah) kurang dalam mengumumkan peraturannya (sosialisasi).

Ketidakefektifan suatu peraturan daerah mungkin terjadi karena beberapa faktor yang saling berkaitan dalam sistem hukum. Menurut Lawrence Meir Friedman, ada 3 (tiga) unsur yang sangat berpengaruh dalam sistem hukum, yaitu substansi, struktur, dan kultur hukum dalam masyarakat. Faktor-faktor yang memengaruhi partisipasi masyarakat di dalam pelaksanaan suatu peraturan daerah. Pertama, substansi Peraturan Daerah yang tidak sesuai dengan nilai masyarakat memancing reaksi masyarakat, sedangkan prosedur partisipasi tidak jelas; Ke-

40 Iza Rumesten RS, "Peranan Pemerintah Daerah terhadap Pengaduan Kekerasan dalam Rumah Tangga", J urnal J ipswari, Vol. 1 No. 1 Tahun 2010, hlm. 21 
dua, kurangnya optimal kinerja aparatur pemerintah yang berwenang dalam menangani setiap penyelewengan atau pelanggaran peraturan. Dalam struktur hukum, masyarakat sebagai subjek hukum memiliki peran yang sangat besar dalam pelaksanaan Peraturan Daerah; ketiga, kurangnya sosialisasi dan kesadaran politik masyarakat yang rendah karena tingkat pendidikan atau karena prioritas hidup sebagian besar masyarakat yang lebih tersita untuk memenuhi kebutuhan pokok sehari-hari. Sehingga kepekaan masyarakat terhadap proses pembentukan suatu Peraturan Daerah sangat rendah ${ }^{41}$.

Sherry Arnstein, menjabarkan peran serta masyarakat berdasarkan kekuatan masyarakat untuk memengaruhi hasil akhir kebijakan pemerintah dapat dilakukan melalui beberapa cara, yaitu manipulasi (manipulation); terapi (therapy); penginformasian (informing); konsultasi (consultation); peredaman (placation); kemitraan (partnership); delegasi kekuasaan (delegated power); dan kendali masyarakat (citizen control). ${ }^{42}$ Berdasarkan tahapan tersebut, Sirajuddin mengklasifikasikan kedelapan tingkat partisipasi tersebut di atas menjadi 3 tingkat. Tingkat pertama diklasifikasikan sebagai tidak partisipasi (non-participation), yaitu tingkat manipulasi dan terapi. Tingkat kedua disebut dengan partisipasi semu (degree of takenism), yaitu tingkat peredaman, konsultasi, dan informasi. Dalam tingkatan kedua ini masyarakat didengarkan dan diperkenankan berpendapat, tetapi tidak memiliki kemampuan dan tidak ada jaminan bahwa pandangan mereka akan dipertimbangkan secara sungguh-sungguh oleh penentu kebijakan. Tingkat ketiga adalah kekuasaan masyarakat (degree of citizen power), yaitu tingkat kemitraan, delegasi kekuasaan, dan kendali masyarakat. Dalam tingkat ini masyarakat memiliki pengaruh dalam proses penentuan kebijakan.

Lebih lanjut Khairul Muluk, ${ }^{43}$ menguraikan 6 (enam) tahapan partisipasi Arnstein di atas dan mengklasifikasikannya dalam 5 tingkat. Na-

\footnotetext{
41 Lawrance M Friedman, 1975, The Legal System: Social Science Perspective, New York: Russel Sage.

42 Siradjuddin, op.cit, hlm. 183.

43 Khairul Muluk, op.cit, hlm. 171
}

mun menurut Muluk hanya 4 tahapan yang tergolong partisipatif, satu tergolong nonpartisipatif karena partisipasi yang ada hanya formalitas, pengerahan masa "bayaran" maupun distorsi informasi. Oleh sebab itu, tahap ini disebut dengan nonpartisipatif. Terakhir kendali warga (bukan lagi sekadar partisipasi, tetapi wargalah yang mengambil keputusan (decision maker). Gambaran lebih jelas lihat di dalam tabel di bawah ini.

Tabel 1: Tingkat Partisipasi Masyarakat

\begin{tabular}{|l|c|c|}
\hline \multicolumn{1}{|c|}{ TINGKAT } & KLASIFIKASI & \\
\hline 6. Kendali & Kendali Warga & \\
5. Delegasi & Partisipasi & Kuat \\
4. Kemitraan & & Sedang \\
3. Konsultasi & & Lemah \\
2. Informasi & & \\
1. Manipulasi & Nonpartisipasi & \\
\hline
\end{tabular}

Apa pun model partisipasi yang disediakan, tidak akan berarti jika masyarakat masih saja bersikap apatis terhadap keputusan atau kebijakan pemerintah. Untuk itu harus ada strategi khusus untuk mendorong masyarakat agar aktif berpartisipasi dalam setiap proses kebijakan. Ada beberapa strategi yang dapat dilakukan untuk menstimulasi partisipasi masyarakat, antara lain: mensolidkan kekuatan masyarakat terutama para stakeholders; memberdayakan masyarakat (membangun kesadaran kritis masyarakat); publikasi hasil-hasil investigasi atau riset-riset yang penting; berupaya mempengaruhi pengambil kebijakan; memunculkan aksi dan gerakan secara kontinu. ${ }^{44}$

Ada beberapa problematika yang terjadi berkaitan dengan hal partisipasi masyarakat dalam peraturan perundang-undangan. Setidaknya ada 3 faktor yang melatarbelakangi munculnya problematika partisipasi, yaitu: faktor masyarakat, yuridis, dan birokrasi. Dari ketiga faktor tersebut ditemukan beberapa permasalahan yang dapat diuraikan, sebagai berikut.

Tabel 2: Problematika Partisipasi Masyarakat ${ }^{45}$

\begin{tabular}{|c|ll|}
\hline FAKTOR & \multicolumn{1}{|c|}{ PROBLEMATIKA } \\
\hline Masyarakat & $\begin{array}{l}\text { Sikap apatis masyarakat. } \\
\text { Kurangnya pengetahuan dan pe- } \\
\end{array}$ & $\begin{array}{l}\text { 2. } \\
\text { mahaman masyarakat. }\end{array}$ \\
\hline
\end{tabular}

44 Sirajuddin dkk., op.cit, hlm. 152

45 lbid, hlm. 149. 


\begin{tabular}{|c|c|}
\hline & $\begin{array}{l}\text { 3. Budaya paternalistis yang masih } \\
\text { kuat mengakar. } \\
\text { 4. Tidak ada reward (berupa tindak } \\
\text { lanjut) partispasi masyarakat } \\
\text { 5. Responsibilitas masyarakat yang } \\
\text { kurang. } \\
\text { 6. Masyarakat tidak mengetahui me- } \\
\text { kanisme penyaluran aspirasi. } \\
\text { 7. Keterbatasan akses masyarakat } \\
\text { informasi. } \\
\text { 8. Kurangnya dukungan elemen ma- } \\
\text { syarakat yang seharusnya mem- } \\
\text { bantu memberdayakan seperti: } \\
\text { LSM atau media massa yang cen- } \\
\text { derung provokatif dan/atau profit } \\
\text { oriented. }\end{array}$ \\
\hline Yuridis & $\begin{array}{l}\text { 1. } \begin{array}{l}\text { Banyak peraturan yang belum ber- } \\
\text { pihak pada kepentingan masya- } \\
\text { rakat. }\end{array} \\
\text { 2. } \begin{array}{l}\text { Belum ada peraturan yang dapat } \\
\text { memaksa pemerintah untuk meli- } \\
\text { batkan rakyat dalam proses pem- } \\
\text { bentukan perda. }\end{array} \\
\text { 3. Belum ada peraturan yang men- } \\
\text { jamin masyarakat mendapatkan } \\
\text { infomasi. } \\
\text { 4. Mudahnya melakukan korupsi ke- } \\
\text { bijakan di bawah payung legali- } \\
\text { tas. } \\
\text { 5. Adanya ketentuan partisipasi yang } \\
\text { tidak mengikat karena tidak ada- } \\
\text { nya sanksi atas pengabaiannya. } \\
\text { Banyak peraturan yang menyang- } \\
\text { kut kewajiban masyarakat (ex. } \\
\text { perda retribusi), tetapi mengabai- } \\
\text { kan hak-hak masyarakat. } \\
\text { Tidak adanya sosialisasi peraturan } \\
\text { atau kebijakan. }\end{array}$ \\
\hline Birokrasi & $\begin{array}{l}\text { 1. Sistem birokrasi yang belum mem- } \\
\text { berikan ruang bagi publik. } \\
\text { 2. Birokrasi diposisikan sebagai me- } \\
\text { sin yang hanya bekerja sesuai ja- } \\
\text { lur. } \\
\text { 3. Tidak ada keterlibatan masyara- } \\
\text { kat dalam pengambilan kebijakan } \\
\text { dengan dalih high cost. } \\
\text { 4. Kurang pahamnya birokrat akan } \\
\text { makna partisipasi secara menda- } \\
\text { sar. } \\
\text { 5. Image birokrasi yang kental de- } \\
\text { ngan uang. } \\
\text { 6. Saluran aspirasi yang kurang baik. } \\
\text { 7. Kerap terjadi mobilitas massa un- } \\
\text { tuk kepentingan politik. } \\
\text { 8. Partai tidak mampu berperan un- } \\
\text { tuk kepentingan rakyat. }\end{array}$ \\
\hline
\end{tabular}

Berikut ini teknik pemberdayaan masyarakat (peningkatan partisipasi masyarakat) dalam proses pembentukan-pembentukan per- aturan daerah. Pertama, membangun relasi pertolongan yang: merefleksikan respons empati; menghargai pilihan dan hak masyarakat; menghargai perbedaan dan keunikan masingmasing kelompok masyarakat; dan menekankan pola kerja sama klien (client partnerships).

Kedua, membangun komunikasi yang: menghormati martabat dan harga diri; mempertimbangkan keragaman individu; dan fokus pada kepentingan masyarakat (umum). Ketiga, terlibat dalam pemecahan masalah yang: memperkuat partisipasi masyarakat dalam pemecahan masalah sosial; menghargai hak-hak masyarakat; merangkai tantangan sebagai kesempatan belajar; dan melibatkan masyarakat dalam pembentukan peraturan daerah dan evaluasinya. Keempat, merefleksikan sikap dan nilai dalam kode etik jabatan pemerintahan yang meliputi: ketaatan terhadap kode etik dan prinsip-prinsip good governance; keterlibatan dalam proses perumusan peraturan daerah; dan penghapusan segala bentuk diskriminasi dan ketidakadilan. ${ }^{46}$

\section{Penutup}

\section{Simpulan}

Kendala dalam proses pembentukan peraturan daerah berupa kelemahan normatif aturan hukum positif (vide UU No. 10/2004) yang hanya memuat 1 (satu) pasal, (vide Pasal 53) yang mengatur partisipasi masyarakat, dan tidak mengatur cara/metode pelaksanaan berpartisipasi masyarakat dalam proses pembentukan Peraturan Daerah di kabupaten/ kota, sehingga metode pelaksanaan hak berpartisipasi masyarakat hanya mengandalkan inovasi Kepala Daerah dan DPRD yang diwujudkan dalam Peraturan Tata Tertib DPRD. Namun, sampai saat ini Peraturan Presiden tentang pembentukan Peraturan Daerah belum diterbitkan, sehingga masih mengacu pada Kepmendagri dan Otoda No. 23 Tahun 2001. Berbagai regulasi sektoral selama ini mendorong dibukanya hak akses publik untuk berperan serta. Namun, pada umumnya, hak untuk berperan serta dalam berbagai

46 Edi Soeharto, 2005, Analisis Kebijakan Publik Panduan Praktis Mengkaji Masalah dan Kebijakan Sosial, Bandung:Alfa Beta, hlm. 68. 
regulasi itu hanya berhenti pada level formulasi Peraturan Daerah, tidak teroperasionalisasikan sampai pada level aturan pelaksanaan yang secara riil dapat digunakan sebagai landasan normatif bagi akses publik. Dalam kondisi tersebut, masyarakat yang secara teoritik memiliki hak untuk mengakses informasi publik dalam proses penetapan kebijakan, tidak sungguhsungguh mampu mempergunakan haknya untuk memantau, mengkritisi dan mengevaluasi kebijakan publik yang akan ditetapkan oleh pejabat publik.

\section{Saran}

Partisipasi masyarakat dalam proses pembentukan Peraturan Daerah harus dikembangkan dengan beberapa cara. Pertama, mengikutsertakan anggota masyarakat yang dianggap ahli dan independen dalam tim atau kelompok kerja dalam pembentukan Peraturan Daerah; kedua, melakukan public hearing (diskusi publik) melalui seminar, lokakarya atau mengundang pihak-pihak yang berkepentingan (stakeholders) dalam rapat-rapat penyusunan Peraturan Daerah; ketiga, melakukan uji sahih kepada pihak-pihak tertentu untuk mendapatkan tanggapan; keempat, mengadakan kegiatan musyawarah atas Peraturan Daerah sebelum secara resmi dibahas oleh institusi yang berkompeten; dan kelima, mempublikasikan rancangan Peraturan Daerah agar mendapatkan tanggapan masyarakat.

\section{Rekomendasi}

Mencermati hal diatas, penulis memberikan beberapa rekomendasi. Pertama, Prinsip kedaulatan rakyat yang bersifat langsung, hendaknya dilakukan melalui saluran-saluran yang sah sesuai dengan prosedur demokrasi (procedural democracy). Sudah seharusnya lembaga perwakilan rakyat dan lembaga perwakilan rakyat daerah diberdayakan fungsinya dan pelembagaannya, sehingga dapat memperkuat sistem demokrasi yang berdasar atas hukum (constitutional democracy) dan prinsip negara hukum yang demokratis (democratische rechtstaat). Kedua, prinsip-prinsip negara hukum hendaklah dibangun dan dikembangkan menurut prinsip- prinsip demokrasi atau kedaulatan rakyat (democratische rechtstaate). Hukum tidak boleh dibuat, ditetapkan, ditafsirkan dan ditegakkan dengan tangan besi berdasarkan kekuasaan belaka (machtsstaati). Prinsip negara hukum tidak boleh ditegakkan dengan mengabaikan prinsipprinsip demokrasi yang diatur dalam UndangUndang Dasar.

\section{Daftar Pustaka}

Abdullah, Alexander. "Desentralisasi dan Undang-undang Otonomi Daerah di Era Reformasi. Jurnal Hukum Vol. 3 No. $1 \mathrm{~J}$ anuari 2010. UII Yogyakarta;

Abe, Alexander. 2005. Perencanaan Daerah Partisipatif. Yogyakarta: Pembaruan;

Ahmad, Rival G. dkk. "Dan Parlemen ke Ruang Publik: Menggagas Penyusunan Kebijakan Partisipatif". J urnal Hukum J entera, Vol. I No. 2 Tahun 2003. PSHK J akarta;

Anggono, Bayu Dwi. "Harmonisasi Peraturan Perundang-undangan di bidang penanggulangan Bencana". Jurnal Mimbar Hukum Vol. 22 No. 2 J uni 2010. FH UGM;

Aziz, Muhammad. "Pengujian Peraturan Perundang-undangan dalam Sistem Peraturan Perundang-undangan Indonesia". J urnal Konstitusi Mahkamah Konstitusi Vol. 7 No. 5 Oktober 2010;

Friedman, Lawrance M. 1975. The Legal System: Social Science Perspective. New York: Russel Sage;

Hamidi, Jazim. 2006. Revolusi Hukum Indonesia (Makna, kedudukan dan Implikasi Hukum Naskah Proklamasi Indonesia 17 Agustus 1945 dalam Sistem Ketatanegaraan RI). Yogyakarta: Kerjasama Konstitusi Press J akarta dengan Citra Media;

Indrati, Maria Farida. "Proses Pembentukan Peraturan Perundang-undangan Pasca Amandemen UUD 1945". Majalah Hukum Nasional No. 1 Tahun 2005;

Limbach, Jutta. "The Concept of the Supremacy of the Constitution". The Modern Law Review, Vol. 64 No. 1 J anuari 2001;

Mahendra, Oka. "Mekanisme Penyusunan dan Pengolahan Program Legislasi Daerah". J urnal Legislasi Indonesia, Vol. 3 No. 1 Maret 2006. Ditjen Peraturan Perundangan-undangan J akarta;

Manan, Bagir. "Konsistensi Pembangungan Nasional dan Penegakan Hukum". Majalah Varia Peradilan No. 275 Oktober 2008; 
Marzuki, Laica. "Konstitusi dan Konstitusionalisme". Jurnal Konstitusi Vol. 7 No. 4 Agustus 2010;

Muluk, Khairul. 2007. Menggugat Partisipasi Publik Dalam Pemerintah Daerah. Malang: LPD FIA UB dan Bayu Media;

Natabaya, AS. "Peningkatan Kualitas Peraturan Perundang-undangan (suatu Pendekatan Input dan Output". Jurnal Legislasi Indonesia, Vol. 4 No. 2 J uni 2007. Ditjen Peraturan Perundangan-undangan J akarta;

Panjaitan, Saut P. "J aminan Perlindungan Konstitusional Hak Tiap Orang Untuk Memperoleh Informasi dan Berkomunikasi". J urnal Simbur Cahaya Vol. XV No. 42 Mei 2010. Unit Penelitian Fakultas Hukum Universitas Sriwijaya Palembang;

Polani, Rosmala. "Pembagian Kewenangan di Wilayah Perairan Pada Era Otonomi Daerah". J urnal Simbur Cahaya Vol. XIII No. 35 J anuari 2008. Unit Penelitian FH Universitas Sriwij aya Palembang;

Potimbang, Hodio. "Faktor-faktor yang Melahirkan Peradilan Massa ditinjau dari Aspek Hukum Pidana". Majalah Varia Peradilan No. 302 J anuari 2011;

Priyanto, I Made Dedy. "Kewenangan Gubernur dalam Pembatalan Perda Kabupaten Tabanan". J urnal Advokasi Vol 1 No 12011. FH Universitas Mahasaraswati Denpasar;

Purba, Hasim. "Sinkronisasi dan Harmonisasi Sistem Hukum Nasional Bidang Pertambangan, Kehutanan, Pertanahan dan Lingkungan Hidup". Jurnal Hukum Equality Vol. 13 No. 2 Agustus 2008. FH USU Medan;

RS, Iza Rumesten. "Peningkatan Fungsi Naskah Akademik dalam Membantu DPRD Menghasilkan Peraturan Daerah Yang Responsif". J urnal Penelitian Hukum Supremasi Hukum Vol. 19 No. 1 Januari 2010. Universitas Bengkulu;

-...-...-... "Peranan Pemerintah Daerah terhadap Pengaduan Kekerasan dalam Rumah Tangga". J urnal J ipswari, Vol. 1 No. 1 Tahun 2010. Palembang;

-.-.--.-.--.-. “Relevansi Partisipasi Masyarakat dalam Perancangan Pembentukan Peraturan Perundang-undangan Yang Responsif". J urnal Simbur Cahaya Vol. XVI No. 44 J anuari 2011 Unit Penelitian FH Universitas Sriwij aya Palembang;
Setiawan, Bonnie, Amalia (ed). "Institute For Global J ustice". Jurnal Keadilan Global No. 01 Tahun 2003;

Sirajudin dkk. 2006. Legislative Drafting; Pelembagaan Metode Partisipasi Masyarakat Dalam Penyelenggaraan Otonomi Daerah. Malang: Corruption Watch dan YAPPIKA;

Soeharto, Edi. 2005. Analisis Kebijakan Publik Panduan Praktis Mengkaji Masalah dan Kebijakan Sosial. Bandung: Alfa Beta;

Subiharta. "Pajak Daerah dan Retribusi Daerah Dalam Perspektif UU No. 28 Tahun 2009". Majalah Varia Peradilan No. 305 April 2011;

Suharizal. "Penguatan demokrasi Lokal Melalui Penghapusan Jabatan Wakil Kepala Daerah". J urnal Konstitusi, Vol. 7 No. 5 Oktober 2010;

Sukriono, Didik. "Membela Desa dengan Desentralisasi dan Melawan desa dengan Demokratisasi". J urnal Yustika Vol. 12 No. 2 Desember 2009. FH Universitas Surabaya; .... "Pembentukan dan Pengawasan Produk Hukum Daerah". J urnal Hukum Adil Vol. 2 No 2 Agustus 2011 FH Univ. Yarsi J akarta;

Syaifuddin, Muhammad; Mada Apriandi Zuhir dan Analisa Yahanan. 2009, Demokratisasi Produk Hukum Ekonomi daerah (Pembentukan peraturan daerah demokratis di bidang ekonomi di Kabupaten/Kota. Malang:Tunggal Mandiri Publishing;

Syawalluddin, M. "Pilkada Langsung dan Penegakan Konstitusionalisme; Bingkai Upaya Mewujudkan Kemaslahatan Umat". J urnal Universalisme Islam Mimbar Akademik Vol. 2 No. 1 J uni 2006 Direktorat Pembinaan Badan Peradilan Agama Islam J akarta;

Taufiqurrahman. "Konvergensi Paradigma daIam Perubahan Karakter Pilihan Hukum Di Bidang Kontrak Jual Beli Barang Internasional". J urnal Repertorium, Vol. 1 No. 1 Tahun 2010;

W. Riawan Tjandra dan Kresno Budi Sudarsono. 2009. Legislative Drafting: Teori dan Teknik Pembuatan Peraturan Daerah. Yogyakarta:Universitas Atmaj aya; 